\title{
Semaphorins in Angiogenesis and Autoimmune Diseases: Therapeutic Targets?
}

\author{
Vijaya Iragavarapu-Charyulu*, Ewa Wojcikiewicz and Alexandra Urdaneta \\ Department of Biomedical Sciences, Florida Atlantic University, Boca Raton, FL, United States
}

The axonal guidance molecules, semaphorins, have been described to function both physiologically and pathologically outside of the nervous system. In this review, we focus on the vertebrate semaphorins found in classes 3 through 7 and their roles in vascular development and autoimmune diseases. Recent studies indicate that while some of these vertebrate semaphorins promote angiogenesis, others have an angiostatic function. Since some semaphorins are also expressed by different immune cells and are known to modulate immune responses, they have been implicated in autoimmune disorders such as multiple sclerosis, rheumatoid arthritis, systemic lupus erythematosus and systemic sclerosis. We conclude this review by addressing strategies targeting semaphorins as potential therapeutic agents for angiogenesis and autoimmune diseases.

Kutty Selva Nandakumar

Southern Medical University, China

Reviewed by:

Luca Tamagnone,

Institute for Cancer Research and

Treatment (IRCC), Italy

Yves Lepelletier,

Université Paris Descartes, France

*Correspondence:

Vijaya Iragavarapu-Charyulu

iragavar@health.fau.edu

Specialty section:

This article was submitted to

Autoimmune and Autoinflammatory

Disorders,

a section of the journal

Frontiers in Immunology

Received: 28 May 2019

Accepted: 12 February 2020

Published: 05 March 2020

Citation:

Iragavarapu-Charyulu V

Wojcikiewicz E and Urdaneta A (2020)

Semaphorins in Angiogenesis and

Autoimmune Diseases: Therapeutic

Targets? Front. Immunol. 11:346.

doi: 10.3389/fimmu.2020.00346

\section{INTRODUCTION}

Semaphorins consist of a large family of conserved proteins originally described as axon guidance molecules during the development of the nervous system. These molecules are now known to be expressed in other adult tissues and function outside of the nervous system (1). Semaphorins since have been discovered to have pleiotropic effects in both health and disease. Semaphorins and their receptors have widespread functional impact physiologically and pathologically as they participate in immune regulation, extracellular matrix remodeling, organogenesis, and angiogenesis (2-4). These molecules therefore play crucial roles in pathophysiology of diseases such as cancer, systemic lupus erythematosus, rheumatoid arthritis, psoriasis, arthritis, proliferative retinopathy, and atherosclerosis among others (5-10). In this review, we discuss semaphorin's structure, receptors, signaling and downstream effects on pathophysiology. We then highlight the roles of semaphorins with respect to angiogenesis and autoimmune disease. We conclude with an emphasis on the role of semaphorins in angiogenesis and autoimmune disease and explore the possibility of targeting semaphorins and their receptors to ameliorate angiogenesis and regulate immune functions.

\section{STRUCTURE, RECEPTORS, AND SIGNALING}

The semaphorin family is divided into eight classes, with invertebrate semaphorins belonging to classes 1 and 2, the vertebrate semaphorins being found in classes 3-7, and the viral semaphorins in class 8 (Figure 1). The Sema domain of semaphorins contains approximately 


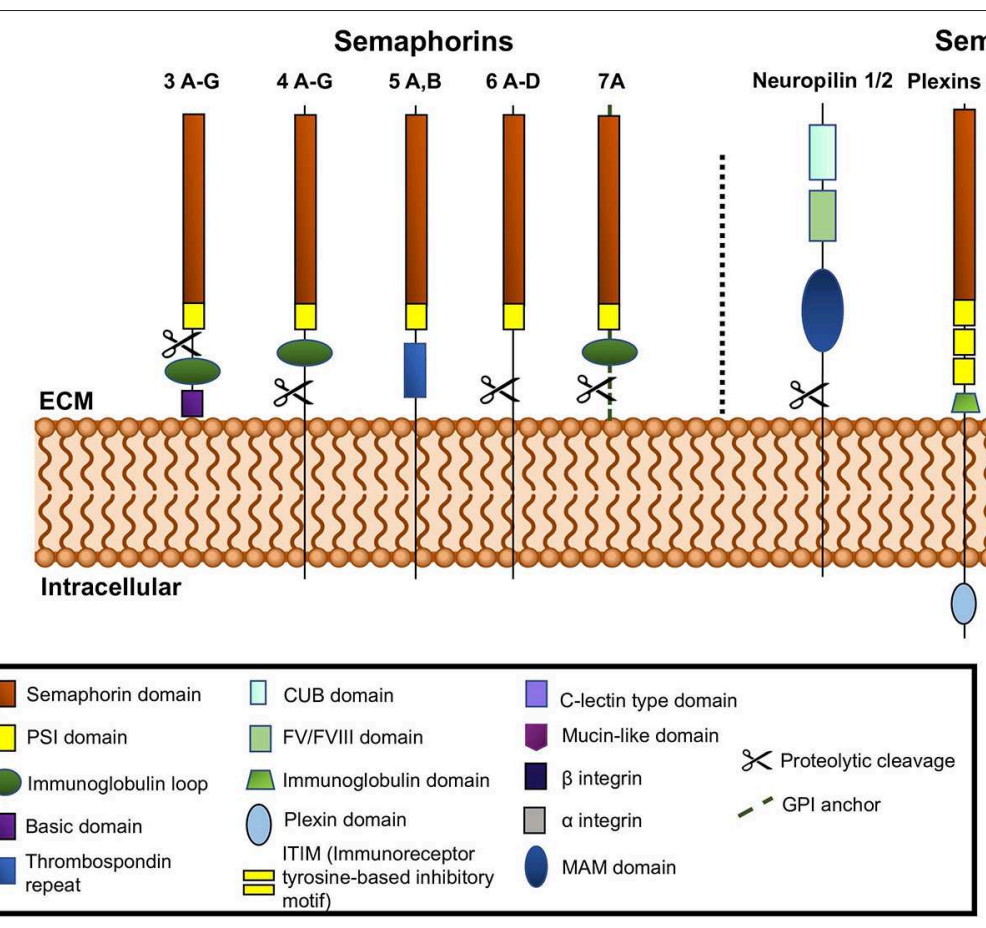

FIGURE 1 | Schematic representation of vertebrate semaphorins and semaphorin receptors. Class 3 is secreted, Classes 4-6 are transmembrane and Class 7 is GPI anchored. Cleavable semaphorins are Sema3, 4, 6, and 7. Receptors for semaphorins are shown on the right side of the figure, neuropilins, plexins, Tim-2, and $\alpha 1 \beta 1$ integrin.

500 amino acids (1). At the carboxy terminus of the Sema domain, all semaphorins also contain a Plexin-semaphorin-integrin (PSI) domain (11). Variations in the C-terminal motifs joining the PSI domain are the key differentiating factor among semaphorins (12). The C-terminus of vertebrate Sema3, 4, and 7 contains an immunoglobulin loop. Sema3 (A-G) contains a basic domain and Sema5 (A-C) contains thrombospondin repeats on their $\mathrm{C}$ termini, respectively. Class 3 semaphorins are secreted, classes 4,5 , and 6 are membrane bound and class 7 is the only member that is GPI-anchored (13) (Figure 1). Semaphorins 3, 4, 6, and 7A are susceptible to cleavage by matrix metalloproteinases and adamlysin family proteases $(14,15)$.

Neuropilins and Plexins serve as semaphorin receptors and are the means through which semaphorins can participate in signal transduction (16-19). Both are transmembrane proteins, with extracellular domains capable of interaction with the semaphorins which can dimerize to mediate their function. Most semaphorins can interact with Plexins directly, while almost all of the class 3 semaphorins (except 3E) bind neuropilins, which form complexes with type A Plexins or Plexin D1. The plexins are required to transduce the signals $(13,16,20,21)$. There are two known neuropilins, -1 and $-2(16,17)$ (Figure 1). Both have short intracellular domains. Their interaction with Plexins, which possess a longer intracellular segment, facilitates their involvement in the transduction of pro-angiogenic signals. The extracellular segment of neuropilins is also the site of binding for VEGF, HGF (hepatocyte growth factor), FGF-2, PDGF-B,
TGF- $\beta$ and other ligands (22-24). The Plexins can more robustly participate in signal transduction via their longer intracellular GTP-ase activating domain (GAP domain). The intracellular GAP domain interacts with GTP-ases directly. Plexins are subdivided into classes A, B, C, and D (Figure 1) and interact directly with semaphorins from classes 4, 5, 6, and 7 and Sema3E $(25,26)$. Plexins A (1-4) and D interact with neuropilins 1 and 2 $(25,26)$.

Semaphorins are a family of proteins that were initially established as repellent cues in axonal guidance and synapse formation during embryogenesis. It is now known that they not only exert a repulsive effect in axonal guidance but, they can also be attractive axonal cues. Sema3A has repellent effects on neurons while Sema3C is known as an attractant. The other members in this family, Sema3D, Sema3E, and Sema3F have both repellent and chemoattractant effects on axons $(27,28)$. Semaphorin $4 \mathrm{~A}$ has been shown to function as a chemoattractant, likely working in concert with other neurotrophic factors to promote neurite outgrowth (29). Sema5A, on the other hand, has been shown to have both attractive and repulsive functions during development $(30,31)$. Of class semaphorins, Sema6A and Sema6B were shown to have chemorepulsive activity via interaction with Plexin A4 in various models of development and angiogenesis (32-34). Although Sema7A promotes axon growth, chemotropic effect was not evident in a model of rat olfactory bulb explant (35). In addition to their role in axonal guidance, semaphorins also play a role in the periphery in regulating angiogenesis and immune responses. 


\section{ROLE OF SEMAPHORINS IN ANGIOGENESIS}

Semaphorins play a significant role in vascular development through the promotion or inhibition of angiogenesis. A balance between pro- and anti-angiogenic signals determine the progression of new blood vessel sprouting. Similar to their function in axonal guidance, semaphorins guide endothelial cells toward tube formation for angiogenesis. Pro-angiogenic semaphorins include Sema3C, Sema4A, Sema4D, Sema6D, and Sema7A, while angiostatic semaphorins include Sema3A, Sema3B, Sema3D, Sema3E, and Sema3F (Table 1). Although Sema3C and Sema4A have been shown to have pro-angiogenic activity, they also were reported to function as anti-angiogenic molecules $(13,53)$ (Table 1).

Class 3 semaphorins are for the most part anti-angiogenic. Class 3 semaphorins exert angiogenic effects through interactions with co-receptors neuropilin-1, -2 (NRP-1,-2) and vascular endothelial growth factor (VEGF) receptor family. Semaphorins 3A, 3B, 3D, 3E, and 3F are exclusively anti-angiogenic (Table 1). The anti-angiogenic activity of Sema3A was demonstrated using cultured rat aortic rings. Sema3A inhibited capillary sprouting and it was further shown to inhibit endothelial cell migration (36). Using an oxygen-induced retinopathy mouse model, $\mathrm{Yu}$ et al. showed that injection of the intravitreous region with Sema3A reduced neovascularized areas and decreased abnormal vessel growth (37). Acevedo et al. showed that Sema3A interferes with VEGF-induced angiogenesis (38). Recently, in a mouse model of bronchial asthma by Adi et al. have shown that treatment of mice with Sema3A reduced inflammatory cell infiltration in bronchioles and angiogenesis was significantly decreased compared to the untreated controls (39). Sema3A and Sema3F are characterized as anti-angiogenic by competing with VEGF in binding to endothelial cell expressed neuropilins (NRP-1/2), the co-receptors for VEGF family (40). Further, Guttmann-Raviv et al. found that co-expression of Sema3A and Sema3F repel endothelial cells more potently than either one of the semaphorins alone (40). Sema3B also was found to have anti-angiogenic activity via NRP-1/-2 which resulted in the repelling of endothelial cells, induction of apoptosis, and inhibition of tube formation (41). Rolny et al. determined the role of Sema3B in tumor angiogenesis and found a reduction in angiogenesis in mice injected with Sema3B transduced tumor cells (42). Similarly, Sema3D/NRP-1 activity was found to inhibit cell motility and tube formation in endothelial cells (47). In contrast, Sema3E was determined to be anti-angiogenic via Plexin-D1, and not NRP signaling on endothelial cells in vitro and in vivo (63). Sakurai et al. reported that Sema3E's antiangiogenic activity can be attributed to its inactivation of $\mathrm{R}$-Ras and stimulation of Arf6 factors which affect integrin activity and inhibit endothelial cell adhesion (63). Other studies have also elucidated Sema3E/Plexin-D1's activity to work as a regulatory mechanism for VEGF-induced angiogenesis by modulating the ratio of endothelial tip and stalk cells (24). Studies with Sema $3 \mathrm{E}^{-1-}$ mice revealed the important role that avascular zones generated by Sema3E play in guiding cardiac vessel development (48). Further, in a rat model of ischemic stroke, it was shown that Sema3E/Plexin-D1 signaling inhibited angiogenesis through regulation of endothelial dynamic deltalike 4 molecule (64).

Within class 3 semaphorins, Sema3C is one of the exceptions due to its bifunctional activity as both a pro-angiogenic and antiangiogenic factor $(13,43,45,65)$. In vitro studies showed Sema3C to induce endothelial cell proliferation, adhesion and directional migration (43). However, other studies report Sema3C to be significantly anti-angiogenic $(13,45)$. Pathologic angiogenesis was shown to be inhibited by Sema3C in an oxygen-induced retinopathy model (45). Further, these authors showed that Sema3C inhibits endothelial tube formation when Human Umbelical Vein Cells were cultured with Sema3C conditioned medium. The anti-angiogenic activity of Sema3C was shown by overexpressing Sema3C in U87 glioblastoma cells and assessing formation of neovasculature in chick chorioallantoic membranes (CAM). Sema3C overexpressing U87 cells did not induce new vessels while control U87 cells had extensive vessels on CAMs (66). Therefore, the effects of this semaphorin may be environment dependent and are ultimately controversial. Sema3F contrary to majority of class 3 semaphorins, was shown to promote extraembryonic angiogenesis via inhibition of Mycregulated throbospondin 1 in yolk sac epithelial cells (50). In contrast, other studies showed that Sema3F is expressed in the avascular outer region of retina and that it exerts anti-angiogenic effects on the retinal and choroidal capillaries (51).

Within class 4 semaphorins, Sema4D was found to have pro-angiogenic effects. Both soluble and membrane-bound forms of Sema4D have been described as pro-angiogenic by signaling through endothelial receptors, Plexin-B1 and PlexinB2. Interaction of Sema4D with Plexin-B1 stabilizes vasculature. Sema4D has been shown to have potent angiogenic effects both in vitro and in vivo by inducing endothelial cell chemotaxis, tube formation, cytoskeletal rearrangements, and vessel growth (55, 56). Increased levels of Sema $4 \mathrm{D}$ have been correlated with poor prognosis in studies of leukemia and mammary carcinoma (6769). Interestingly, this semaphorin has been shown to play a role in vasculogenic mimicry in a non-small cell lung cancer model. $\mathrm{Xia}$ et al. found that the interaction of Sema4D with PlexinB1 promoted vasculogenic mimicry while inhibition of Sema4D decreased vasculature (70). In contrast to Sema4D, Sema4A was found to have dual activity as both a pro- and anti-angiogenic factor. The pro-angiogenic effect of Sema4A in the context of tumor is indirectly mediated by signaling through Plexin-D1expressing macrophages, which induce VEGF-A expression and thereby enhance tumor vasculature (52). However, depending on the environment, Sema4A inhibits angiogenesis using the same receptor, Plexin-D1 (53). Therefore, the role of Sema4A in tumors is still controversial.

The only member in class 5 semaphorins reported to have angiogenic activity is Sema5A. This semaphorin has been shown to be necessary for normal cranial vasculature development and be a regulator of angiogenesis by promoting endothelial cell migration and proliferation, while also reducing apoptosis $(57,58)$. 
TABLE 1 | The role of semaphorins in mediating angiogenesis and autoimmune diseases.

\begin{tabular}{|c|c|c|}
\hline Semaphorin & Angiogenesis & References \\
\hline Semaphorin $3 A$ & & $(36-40)$ \\
\hline Semaphorin 3B & & $(41,42)$ \\
\hline Semaphorin 3C & & $3,44)$ \\
\hline Semaphorin 3D & & $(47)$ \\
\hline Semaphorin 3E & & $(48,49)$ \\
\hline Semaphorin 3F & & $0,50)$ \\
\hline Semaphorin 4A & & \\
\hline Semaphorin 4D & & $(55,56)$ \\
\hline Semaphorin 5A & & $(57,58)$ \\
\hline Semaphorin 6D & & (59) \\
\hline Semaphorin 7A & & $(60-62)$ \\
\hline
\end{tabular}

$\checkmark$ Anti-angiogenic; 1 Pro-angiogenic.

Among class 6 semaphorins, Sema6D acts by binding to a receptor complex composed of PlexinA1 and either Off Track (OTK) or VEGFR2. Binding of Sema6D to these receptor complexes results in varying effects during cardiac development including, endothelial cell repulsion or attraction, respectively (2). In models of gastric cancer, signaling due to Sema6D and Plexin-A1/VEGFR2 interaction results in effects similar to VEGF binding alone. In addition, Sema6D/Plexin-A1 expression is positively correlated with the expression of VEGFR2, therefore contributing to its angiogenic and tumorigenic properties (59). Poor prognosis of gastric cancer has been correlated with Sema6D expression and increased angiogenesis (59) (Table 1).

Class 7 semaphorins have also been found to have proangiogenic effects (Table 1). In particular, Sema7A was determined to mediate angiogenesis through signaling via Plexin- $\mathrm{C} 1$ and $\beta 1$ integrins. Using a corneal neovascularization model, Ghanem et al. showed that Sema7A is expressed in vascularized corneas and that basic fibroblastic growth factor (bFGF) enhances the expression of Sema7A (60). The pro-angiogenic function of Sema7A in promoting intraplaque neovascularization was found to be mediated through $\beta 1$ integrin and activation of VEGFA/VEGFR2 (61). Tumor angiogenesis is regulated by stromal cells such as macrophages, neutrophils and cancer associated fibroblasts (71). Tumor angiogenesis is affected by infiltration of leukocytes, e.g., tumor associated macrophages (TAMs) (72). Due to its chemotactic effects, Sema7A could attract TAMs which could then regulate angiogenesis in the tumor microenvironment (73). Garcia-Areas et al. delineated the angiogenic role of Sema7A in promoting tumor growth. In this study, it was shown that co-culture of Sema7A with macrophages induces the production of angiogenic chemokines, CCL2, CXCL2/MIP2. Further, implantation of Sema7A gene-silenced mammary tumor cells resulted in decreased in vivo tumor angiogenesis compared to the wild type tumors (62). Thus, in the context of tumor, Sema7A could promote angiogenesis in multiple ways. Further, Black et al. revealed a novel role for Sema7A in promoting lymphangiogenesis in breast cancer and reported that loss of Sema7A reduces both tumor cell invasion and activation of $\beta 1$-integrin receptor (74).

\section{ROLE OF SEMAPHORINS IN AUTOIMMUNE DISEASE}

Semaphorins through interaction with their receptors, in addition to playing a role in angiogenesis, regulate immune homeostasis, and tissue inflammation. Neuropilins are important for the initiation of the primary immune response as NRP-1 has been shown to mediate contact between DCs and T cells in the immunologic synapse (75). Autoimmune disorders are characterized by dysregulated immune responses associated with decreased T regulatory cells and overactive responses by $\mathrm{B}$ and $\mathrm{T}$ cells against self-molecules. $\mathrm{T}$ regulatory development is guided by the transcription factor, Foxp3 (76). In a mouse model, it was shown that $\mathrm{T}_{\text {reg }}$ cells express NRP-1. However, it is important to note NRP-1 is not a marker of human Foxp3 $\mathrm{T}_{\text {reg }}$ cells (77). The interaction of NRP-1 with immune cell-expressed Sema4A in mice further potentiates $\mathrm{T}_{\text {reg }}$ cell function (78). Further, peripheral tolerance is also maintained by dendritic cells that could prevent activation of self-reactive cells which can then lead to inhibition of autoimmunity. The receptors expressed at the immunological synapse between dendritic cells (DCs) and T cells can therefore affect the outcome between development of tolerance or autoimmune response (79).

Semaphorins, Sema3A, Sema3E, Sema4A, Sema4D, Sema5A, Sema6D, and Sema7A may be considered as "immune semaphorins" since they are involved in physiological and pathological immune responses (80). Autoimmune diseases, such as systemic lupus erythematosus (SLE), rheumatoid arthritis (RA), multiple sclerosis (MS), and systemic sclerosis or scleroderma (SSc), are characterized by chronic inflammation and subsequent tissue damage resulting from cellular and humoral immune responses to self-antigens. Inflammation affects the expression of semaphorins and their receptors and recent studies show that several members of the semaphorin family are aberrantly expressed in autoimmune disorders (Table 2) (89, 90). In this review, we focus on immune semaphorins as one of the mediators of autoimmune diseases.

The secreted class 3 semaphorins modulate immune responses by binding and signaling through neuropilins and their association with Plexins. The members of the semaphorin 3 family that function in pathogenesis of autoimmune diseases are Sema3A, Sema3C, Sema3E, and Sema3F. Sema3A is a potent immunoregulatory molecule and has been shown to suppress the over-activity of T and B lymphocytes (91-93). Activation of naïve $\mathrm{T}$ cells requires an immunological synapse with dendritic 
TABLE 2 | The role of semaphorins in mediating autoimmune diseases.

\begin{tabular}{llc}
\hline Semaphorin & Autoimmune disease & References \\
\hline Semaphorin 3A & $\begin{array}{l}\text { Rheumatoid Arthritis (RA), } \\
\text { asthma, systemic sclerosis (SSC), } \\
\text { Multiple Sclerosis (MS), systemic }\end{array}$ & \\
& lupus erythematosus (SLE) & \\
Semaphorin 3C & RA & \\
Semaphorin 3E & SSc \\
Semaphorin 3F & MS \\
Semaphorin 4A & Experimental autoimmune \\
Semaphorin 4D & MS/EAE, RA & (83) \\
Semaphorin 5A & RA & (84) \\
Semaphorin 6D & EAE & RA, MS/EAE, SSc, COPD \\
Semaphorin 7A & RA & (85-87) \\
\hline
\end{tabular}

cells in the secondary lymphoid organs. The immunosuppressive role of Sema3A on $\mathrm{T}$ cell proliferation was first described by Lepelletier et al. (94). NRP-1, the Sema3A receptor expressed by activated T cells and DCs., was found to play an important role in forming DC-T cell synapse (75). Lepelletier et al. found that the high levels of Sema3A produced in the later stage of DC-T cells co-cultures inhibited T cell proliferation. Thus, the induced Sema3A expression by both DCs and T cells during the latter part of the immune response could be regulating this response (94). Either neutralization by blocking antibodies or by an antagonist peptide of Sema3A increased T cell proliferation (94). These authors have shown that the immunomodulatory function of Sema3A is mediated by actin cytoskeleton reorganization that has downstream effects on signal transduction (94) (Figure 2B). Solomon et al. have shown that NRP-1 attenuates autoreactivity of myelin oligodendrocyte glycoprotein (MOG)induced experimental autoimmune encephalitis (EAE) and that lack of NRP-1 aggravates the disease (95). Furthermore, Lepellier et al. have also shown that both Sema3A and Galectin-1 expressed by mesenchymal stem cells inhibit $\mathrm{T}$ cell proliferation through NRP-1 binding (96).

Other studies have shown that Sema3A downregulates T cell activation and modulates immune responses through activation of T regulatory cells (81). Further, co-culture of B regulatory cells with Sema3A upregulated expression of CD72 and enhanced the production of immunoregulatory cytokines, IL-10 and TGF- $\beta$ (97) (Figure 2B). More significantly, culturing of Sema3A with cytosine-phosphodiester-guanine oligodeoxynucleotides (CpGODN)-stimulated B cells from SLE patients resulted in decreased TLR-9 expression that could then have an effect on cytokine production profile (98). Several studies have linked pathogenesis of autoimmune diseases to lower Sema3A levels and serum levels were reported to inversely correlate with disease activity of SLE, RA and SSc (81, 97-99) (Table 2). Catalano reported downregulation of Sema3A in T cells from RA patients (91). Further, transient ectopic expression of Sema3A inhibited clinical manifestation of collagen induced arthritis (91). Rezaeepoor et al. found that serum levels of Sema3A and its expression in peripheral blood mononuclear cells were significantly decreased in MS patients compared to normal subjects (100). In contrast, Williams et al. showed an increase in expression of Sema3A at the inflammatory regions from brains of human patients (84). It is possible that Sema3A is involved in the regeneration of oligodendrocytes, and deregulation of Sema3A could impair recruitment of oligodendrocyte precursors preventing repair. $\mathrm{T}$ helper cell differentiation and transmigration through the blood brain barrier are also detrimental in mediating pathogenesis of MS. Lack of Sema3A or its receptors resulted in impaired T cell priming and studies show that inhibiting immune cell migration prevents MS relapse (85). These studies indicate that Sema3A downregulates autoimmune disease by suppressing both $\mathrm{B}$ and $\mathrm{T}$ cell activity (93). The role of Sema3A in SSc is unclear, while some studies have shown reduced expression of Sema3 A in serum and in regulatory $\mathrm{T}$ cells, others did not detect any differences in expression levels between SSc patients and normal individuals $(81,82)$.

Another member of class 3 semaphorins, Sema3C, has been implicated in RA (Table 2). Miller et al. showed that synovial tissue samples from RA patients were positive for Sema3C and synovial macrophages and fibroblasts were found to express Sema3C by immunofluorescence (83). In contrast to decreased Sema3A levels in SSc, elevated levels of Sema3E were found in both serum and skin from SSc patients (49) (Table 2). Impaired angiogenic response following tissue ischemia and hypoxia is an important feature of SSc (101). Thus, the anti-angiogenic effect of the Sema3E and Plexin-D1 interaction results in the dysregulation of vascular tone control and may contribute to pathogenesis of SSc. The last member of the semaphorin 3 family implicated in autoimmunity is Sema3F. The transcripts of Sema3F were upregulated in the brains of MS patients and in experimental models of demyelination $(84,102)$. Increased Sema3F expression was associated with glial cell infiltrates in the inflammatory lesions (84). These authors suggested Sema3F expression influences oligodendrocyte precursor cell recruitment that could promote re-myelination.

Class 4 semaphorins also play a role in autoimmune diseases (Table 2). The effects of Sema4 members are mediated by binding to class B Plexins, Tim-2, CD72, NRP-1, and NRP-2 among others (4, 103-106) (Figure 1). Additionally, Sema4A and Sema4D may be cleaved producing soluble forms (21). Both of these semaphorins have been associated with pathology of RA. Levels of Sema4A and Sema4D are increased in serum and synovial fluid of RA patients $(87,107)$. These elevated levels have been positively correlated with serum levels of inflammatory cytokines, TNF- $\alpha$ and IL-6 (107). Sema4A is expressed in activated $\mathrm{T}$ cells and DCs and plays a critical role in the immune system as it is involved in antigen-specific $\mathrm{T}$ helper cell responses $(108,109)$. Pathogenesis of MS is mediated in part by dysregulated helper $\mathrm{T}$ cells. Since Sema4A plays a role in $\mathrm{T}$ helper cell differentiation, it has been associated with pathogenesis of MS. Further, the use of anti-Sema4A (anti-CD100) monoclonal antibodies significantly suppressed the development of EAE (108). Others have shown that mice lacking Sema4A have diminished TH1 responses; this suggests that these mice may be less prone to EAE, which is mediated by TH1 cells (109). Another member of class 4 semaphorins which is 


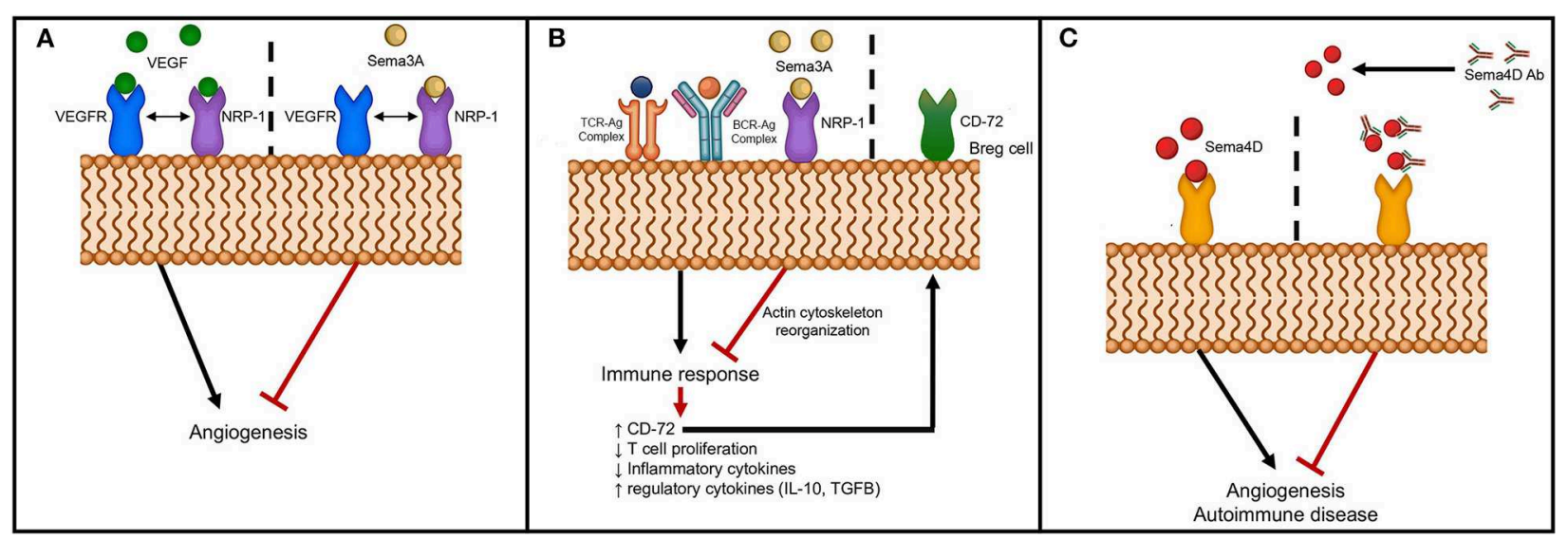

FIGURE 2 | Schematic of semaphorin interaction with receptors to modulate angiogenesis and autoimmunity. (A) Sema3A interferes with angiogenesis through binding to NRP-1, the co-receptor for VEGFR; (B) Sema3A dampens immune response through binding to NRP-1 with downstream effects on actin cytoskeletal reorganization and upregulation of CD72 on B regulatory cells; and (C) Inhibition of angiogenesis and autoimmunity by neutralizing anti-Sema4D antibody.

implicated in autoimmune disease is Sema4D. While Sema4D is expressed at low levels in B cells, it is expressed at higher levels in T cells. The interaction of T cell expressed Sema4D with CD72 on DCs augments T cell activation $(110,111)$ (Table 2). By binding to Plexin B1 and CD72, Sema4D promotes activation of $B$ cells to induce antibody production and antigen specific $T$ cells $(86,110,112)$. Okuno et al. demonstrated attenuation of MOGspecific EAE development by adoptive transfer of MOG-specific $\mathrm{T}$ cells into Plexin-B1 deficient mice, which indicates the role of the Sema4D-Plexin B1 interaction in pathogenesis of EAE (88).

Among class 5 semaphorins, Sema5A is the only member thus far that has been associated with autoimmune disease (Table 2). High levels of secreted Sema5A were found in circulation of patients with RA (113). Further, treatment of primary T cells and NK cells with soluble form of recombinant Sema5A resulted in increased proliferation and secretion of proinflammatory $\mathrm{TH} 1$ and TH17 cytokines (113).

A class 6 semaphorin, Sema6D, is expressed in lymphoid populations including T, B and NK cells. O'Connor et al. studied the regulation of $\mathrm{T}$ cells by Sema6D, the stimulation of which resulted in enhanced Sema6D expression (114). Sema6D interacts with Plexin A1 and TREM-1/DAP12 complex to activate T cells and generate antigen specific $\mathrm{T}$ cells (85). In mice lacking Plexin A1, production of antigen-specific T cells is defective. Therefore, these mice are less prone to developing EAE (21). These studies suggest a potential role for Sema6D in the development of MS.

Semaphorin 7A, an immune semaphorin, plays an important role in regulating innate immune cells. In the immune system, Sema7A is expressed by activated $\mathrm{T}$ lymphocytes and stimulates not only monocytes, but also macrophages to produce proinflammatory cytokines. Sema7A was found to induce the production of proinflammatory cytokines through monocytes (73) and activated T-cells (4) (Figure 1). By binding to $\alpha 1 \beta 1$ integrin in both monocytes (115) and T cells, Sema7A activates the MAP kinase pathway $(43,115)$. This finding departs from the notion that semaphorins signal only through Plexins and neuropilins, the traditional semaphorin receptors. As a GPIanchored protein, Sema7A is recruited to lipid rafts that accumulate at the immunological synapse between $\mathrm{T}$ cells and macrophages. Direct immunization of Sema7A-deficient mice with MOG peptide and adoptive transfer of antigenspecific Sema7A-deficient T cells do not induce T-cell-mediated immune responses (115). Sema7A-knockout mice resist the development of inflammation after hapten-induced contact hypersensitivity (85). In human studies, Sema7A has been shown to be involved in chronic inflammatory diseases like chronic obstructive pulmonary disease (COPD) (116) and RA (117) (Table 2).

In addition to its role in the immune response, Sema7A, the only GPI-anchored semaphorin, functions as a chemoattractant and stimulates neuronal migration. Other semaphorins such as Sema4D (118), Sema4C (119), and Sema6A (120) have also been shown to promote neuronal migration. More importantly, Sema7A promotes dendricity not only in axons (35), but also in melanocytes (121), osteoclasts (122), activated T-cells (4), and monocytes (73). Expression of Sema7A has also been associated with fibrosis, inflammation and immune modulation, and is shown to play a role in RA, MS and SSc (123-125) (Table 2).

Sema7A is cleaved off the membrane by ADAM-17 (15). In patients with RA, the elevated levels of soluble Sema7A in both serum and synovial fluid have been correlated with disease severity $(99,125)$. Xie et al. showed that soluble Sema7A activates $\mathrm{TH} 1$ cells resulting in increased production of the inflammatory cytokines IL-6 and IL-17 that could contribute to pathogenesis of RA (125). Costa et al. studied the expression of Sema7A in lesions of MS patients and correlated the levels to the severity of the inflammation in the lesions (126). Using an EAE mouse model, Gutierrez-Franco et al. elucidated the role of Sema7A in MS by comparing demyelination or cell death in Sema7A deficient mice with wild type mice. Mice deficient in Sema7A had impaired inflammatory cellular infiltrates into the central 
nervous system and reduced demyelination compared to wild type littermates (124). Further, decreased circulating levels of Sema7A have been associated with patients with SLE compared to healthy controls (99).

Sema7A is also an important regulator of tissue remodeling by inducing fibrosis $(116,127)$. A pulmonary fibrosis study showed that expression of Sema7A and its receptors, Plexin $\mathrm{C} 1$ and $\alpha 1 \beta 1$ integrins, are induced by TGF- $\beta 1$ contributing to TGF- $\beta 1$-derived fibrosis and tissue remodeling mediated by the PI3K/AKT pathway (116). Similarly, recent studies found Sema7A in astrocytes and, accumulation of Sema7A in fibrotic tissue following spinal cord injury via activation the PI3K/AKT pathway (127). Sema7A knockout mice crossed with TGF- $\beta 1$ overexpressing transgenic mice exhibited decreased severity in lung fibrosis compared to TGF- $\beta 1$ overexpressing transgenic control mice (123). Collagen-producing fibrocytes and B cells expressing Sema7A contribute to pulmonary fibrosis and thus could lead to SSc (123).

\section{TARGETING SEMAPHORINS TO CONTROL ANGIOGENESIS AND AUTOIMMUNE DISEASES}

Numerous studies have implicated semaphorins as therapeutic targets for angiogenesis and autoimmune diseases. However, the strategies depend on various factors. For example, semaphorins can either promote or inhibit angiogenesis depending on the receptor they engage with, whether it is a transmembrane or a secreted molecule, and which signaling pathways are activated. Further, semaphorin signaling is modulated by the receptor and co-receptor complex. Thus, different combinations of receptor complexes can affect signaling pathways to result in altered cytokine production, cell proliferation and migration and, ultimately, causing either angiogenesis or angiostasis. Similarly, dysregulated immune responses contributing to autoimmune disorders are also affected by transmembrane vs. secreted semaphorins, the receptors engaged and the signaling pathways activated. All of these factors must be considered when designing therapeutic strategies. So, what are some of the possible strategies to control angiogenesis and/or autoimmune diseases mediated by semaphorins? Some strategies include the use of soluble semaphorins, small molecules or blocking antibodies to inhibit signaling, and antagonist peptides to inhibit sema-receptor complexes. Addressed in this review are soluble semaphorins and antibodies to ameliorate angiogenesis and autoimmune disease.

Studies show that Class 3 semaphorins have anti-angiogenic activity (128-130). Sema3A, -C, and E have all been shown to be anti-angiogenic. Thus, class 3 semaphorins have been used as "physiological vascular normalizing agents" for anticancer therapy and thereby, aid in enhancing the efficacy and overcoming acquired resistance to anti-angiogenic therapies (130). In vitro studies show that migration of endothelial cells cultured in the presence of angiogenic inducers is inhibited by Sema3A and Sema3F (38, 129, 131). In mouse models of cancer, systemic delivery of Sema3A impaired angiogenesis and metastasis (128). A possible mechanism by which Sema3A inhibits angiogenesis is by competing for neuropilin, a coreceptor for VEGF (Figure 2A). Anti-angiogenic activity of Sema3E is mediated through Plexin D1 to regulate endothelial cells and development of vasculature (132). Sema3E-plexin D1 interaction inhibits angiogenesis by suppressing the VEGF signaling pathway (133). It may be postulated that semphorins such as Sema3A or Sema3E can be used as anti-angiogenic agents to block the pro-angiogenic activity of semaphorins such as Sema4A or Sema4D. Using an oxygen-induced retinopathy model, Yang et al. found that local administration of Sema3C inhibits pathological angiogenesis (45). Further, both tumor angiogenesis and lymphangiogenesis were inhibited by the stabilized form of Sema3C (65). In a glioblastoma model, ectopic expression of Sema3D or Sema3E reduced tumor growth (134). Using a RipTag2 pancreatic tumor model, Tamagnone et al. showed inhibition of tumor angiogenesis by administering Sema3E via an Alzet pump delivery system (135). These studies indicate that semaphorins may be used as therapeutic agents to regulate angiogenesis. However, a potential problem with the use of semaphorins as treatment agents for angiogenesis are the possible side effects, e.g., those caused by suppressing the VEGF pathway by Sema3E/Plexin D1.

In terms of its possible use in treating autoimmune diseases, Sema3A is a viable candidate as it has been shown to have immunoregulatory activities on both innate and adaptive immunity (136). Treatment with Sema3A and subsequent binding to NRP-1 suppresses the immune response and also enhances B regulatory cells by upregulating CD72 (137) (Figure 2B). In a mouse model of RA, overexpression of Sema3A partially attenuated disease progression (91). Further, treatment of mice with Sema3A was beneficial in that it reduced lupus nephritis (136). Behar et al. showed that increased Sema3A expression on B regulatory cells and that addition of Sema3 A to activated $\mathrm{B}$ cells resulted in downregulation of TLR-9 expression (136). Sema3A could therefore be added to the arsenal of treatment options for MS, SLE and other autoimmune disorders.

Antibodies provide an attractive treatment option to directly target specific molecules to block the action of semaphorins and thus, reduce angiogenesis or suppress autoimmune diseases. However, there are difficulties in targeting semaphorins due to: (1) the conserved Sema domain in semaphorins and Plexins; (2) redundancy in semaphorins; and (3) receptors that bind to molecules other than semaphorins. Despite these difficulties, antibodies have been designed and manufactured providing positive results. Semaphorins interact with their receptors, neuropilins, and Plexins, to mediate the downstream effects. Studies have shown that targeting neuropilins, Plexins, or semaphorins with specific antibodies results in decreased angiogenesis. Semaphorin $4 \mathrm{D}$ blocking antibody was used to assess the level of inhibition of angiogenesis in vitro and in vivo. Reduced vessel counts were observed in mice that received anti-sema4D antibodies indicating reduced angiogenesis (56) (Figure 2C). Kong et al. using anti-NRP-1 peptide in both in vitro and in vivo studies found suppression of VEGF-induced angiogenesis and experimental arthritis (138).

Blocking of semaphorins and preventing interaction with their receptors provides a unique strategy to inhibit autoimmune 
diseases. It is known that CD4 T cells proliferate and differentiate into TH1 or TH2 cells when presented with an antigen by DCs. TH1 cells not only promote cell-mediated immunity but are involved in development of autoimmune disease. NRP-1 is one of the molecules involved in stabilization of DC-T cell interaction (75). Incubation of either T cells or DCs with NRP-1 antibodies reduced $\mathrm{T}$ cell proliferation. This could have implications in developing treatment options for autoimmune diseases. Using an in vivo experimental model of axotomy of the rat optic nerve, Shirvan et al. demonstrated that injecting anti-Sema3A antibodies inhibited retinal ganglion cell loss and neuronal protection from degeneration was observed (139). These studies led to the use of the semaphorin antibodies and peptides as possible treatment options for immune mediated diseases. Administration of anti-Sema4A monoclonal antibodies during MOG-induced EAE blocked the development of EAE (108). Other studies have shown that use of neutralizing anti-Sema4D antibodies in treating EAE and RA decreased disease severity (140). Fisher et al. determined that anti-Sema4D antibodies ameliorate collagen-induced arthritis and reduced inflammation in a collagen-induced arthritis model (140). In other studies, administration of anti-Sema4D reduced the severity of RA (107), and using anti-Sema7A antibodies, Xie et al. reported inhibition of collagen induced arthritis (125) (Figure 2C). Using antibodies as therapeutics, one must be cognizant of off-target effects on vasculature, vascularized organs, brain, and spinal cord. In addition to antibodies peptides targeting semaphorin receptors may be an alternative strategy to ameliorate autoimmune diseases. A recent study used Plexin-A1 antagonist to counteract the anti-migratory effect of Sema3 A in oligodendrocytes. It was

\section{REFERENCES}

1. Kolodkin AL, Matthes DJ, Goodman CS. The semaphorin genes encode a family of transmembrane and secreted growth cone guidance molecules. Cell. (1993) 75:1389-99. doi: 10.1016/0092-8674(93)90625-Z

2. Toyofuku T, Zhang H, Kumanogoh A, Takegahara N, Suto F, Kamei J, et al. Dual roles of Sema6D in cardiac morphogenesis through regionspecific association of its receptor, Plexin-A1, with off-track and vascular endothelial growth factor receptor type 2. Genes Dev. (2004) 18:435-47. doi: $10.1101 / \operatorname{gad} .1167304$

3. Bielenberg DR, Pettaway CA, Takashima S, Klagsbrun M. Neuropilins in neoplasms: expression, regulation, and function. Exp Cell Res. (2006) 312:584-93. doi: 10.1016/j.yexcr.2005.11.024

4. Suzuki K, Kumanogoh A, Kikutani H. Semaphorins and their receptors in immune cell interactions. Nat Immunol. (2008) 9:17-23. doi: 10.1038/n i1553

5. Adamis AP, Miller JW, Bernal MT, D’Amico DJ, Folkman J, Yeo $\mathrm{TK}$, et al. Increased vascular endothelial growth factor levels in the vitreous of eyes with proliferative diabetic retinopathy. Am J Ophthalmol. (1994) 118:445-50. doi: 10.1016/S0002-9394(14)7 5794-0

6. Folkman J. Angiogenesis in cancer, vascular, rheumatoid and other disease. Nat Med. (1995) 1:27-31. doi: 10.1038/nm0195-27

7. Couffinhal T, Kearney M, Witzenbichler B, Chen D, Murohara T, Losordo DW, et al. Vascular endothelial growth factor/vascular permeability factor (VEGF/VPF) in normal and atherosclerotic human arteries. Am J Pathol. (1997) 150:1673-85.

8. Carmeliet P. Angiogenesis in health and disease. Nat Med. (2003) 9:653-60. doi: $10.1038 / \mathrm{nm} 0603-653$ shown that blocking PlexinA1, the receptor of Sema3A enhanced myelin content and thus locomotor activity in an in vivo model of EAE (141).

\section{CONCLUSION}

Considering that the field of study of semaphorins is relatively new, tremendous progress has been made in understanding their roles in various diseases affected by angiogenesis and autoimmune reactivities. Designing effective strategies to reduce pathogenicity associated with these molecules is crucial. In this review, we discussed the role of immune semaphorins, Sema3A, $3 \mathrm{C}, 3 \mathrm{E}, 3 \mathrm{~F}, 4 \mathrm{~A}, 4 \mathrm{D}, 5 \mathrm{~A}, 6 \mathrm{D}$, and $7 \mathrm{~A}$ in angiogenesis and autoimmune diseases. We then highlighted the inhibition of semaphorins or their receptors in ameliorating angiogenesis and autoimmune diseases.

\section{AUTHOR CONTRIBUTIONS}

VI-C selected the topic and wrote the introduction, autoimmune disease, and therapeutic approach and conclusion sections. EW wrote the semaphorin structure and signaling and prepared the Table. AU wrote the angiogenesis section and prepared Figures 1, 2. All of the authors critically read and edited the manuscript.

\section{FUNDING}

This work was supported by Private donation from Pancreatic Cancer Foundation.
9. MacDonald IJ, Liu SC, Su CM, Wang YH, Tsai CH, Tang CH. Implications of angiogenesis involvement in arthritis. Int J Mol Sci. (2018) 19:E2012. doi: 10.3390/ijms19072012

10. Zhong W, Montana M, Santosa SM, Isjwara ID, Huang YH, Han KY, et al. Angiogenesis and lymphangiogenesis in corneal transplantation-a review. Surv Ophthalmol. (2018) 63:453-79. doi: 10.1016/j.survophthal.2017.12.008

11. Love CA, Harlos K, Mavaddat N, Davis SJ, Stuart DI, Jones EY, et al. The ligand-binding face of the semaphorins revealed by the highresolution crystal structure of SEMA4D. Nat Struct Biol. (2003) 10:843-8. doi: $10.1038 /$ nsb977

12. Zhou Y, Gunput RA, Pasterkamp RJ. Semaphorin signaling: progress made and promises ahead. Trends Biochem Sci. (2008) 33:161-70. doi: $10.1016 /$ j.tibs.2008.01.006

13. Toledano S, Nir-Zvi I, Engelman R, Kessler O, Neufeld G. Class-3 semaphorins and their receptors: potent multifunctional modulators of tumor progression. Int J Mol Sci. (2019) 20:556. doi: 10.3390/ijms20030556

14. Basile JR, Holmbeck K, Bugge TH, Gutkind JS. MT1-MMP controls tumorinduced angiogenesis through the release of semaphorin 4D. J Biol Chem. (2007) 282:6899-905. doi: 10.1074/jbc.M609570200

15. Fong KP, Barry C, Tran AN, Traxler EA, Wannemacher KM, Tang HY, et al. Deciphering the human platelet sheddome. Blood. (2011) 117:e15-26. doi: 10.1182/blood-2010-05-283838

16. Chen H, Chedotal A, He Z, Goodman CS, Tessier-Lavigne M. Neuropilin2 , a novel member of the neuropilin family, is a high affinity receptor for the semaphorins Sema E and Sema IV but not Sema III. Neuron. (1997) 19:547-59. doi: 10.1016/S0896-6273(00)80371-2

17. He Z, Tessier-Lavigne M. Neuropilin is a receptor for the axonal chemorepellent Semaphorin III. Cell. (1997) 90:739-51. doi: 10.1016/S0092-8674(00)80534-6 
18. Comeau MR, Johnson R, DuBose RF, Petersen M, Gearing P, VandenBos T, et al. A poxvirus-encoded semaphorin induces cytokine production from monocytes and binds to a novel cellular semaphorin receptor, VESPR. Immunity. (1998) 8:473-82. doi: 10.1016/S1074-7613(00)80552-X

19. Winberg ML, Noordermeer JN, Tamagnone L, Comoglio PM, Spriggs MK, Tessier-Lavigne $M$, et al. Plexin $A$ is a neuronal semaphorin receptor that controls axon guidance. Cell. (1998) 95:903-16. doi: 10.1016/S0092-8674(00)81715-8

20. Kolodkin AL, Levengood DV, Rowe EG, Tai YT, Giger RJ, Ginty DD. Neuropilin is a semaphorin III receptor. Cell. (1997) 90:753-62. doi: 10.1016/S0092-8674(00)80535-8

21. Nishide M, Kumanogoh A. The role of semaphorins in immune responses and autoimmune rheumatic diseases. Nat Rev Rheumatol. (2018) 14:19-31. doi: 10.1038/nrrheum.2017.201

22. Gagnon ML, Bielenberg DR, Gechtman Z, Miao HQ, Takashima S, Soker $S$, et al. Identification of a natural soluble neuropilin-1 that binds vascular endothelial growth factor: in vivo expression and antitumor activity. Proc Natl Acad Sci USA. (2000) 97:2573-8. doi: 10.1073/pnas.040337597

23. Gu C, Rodriguez ER, Reimert DV, Shu T, Fritzsch B, Richards LJ, et al. Neuropilin-1 conveys semaphorin and VEGF signaling during neural and cardiovascular development. Dev Cell. (2003) 5:45-57. doi: 10.1016/S1534-5807(03)00169-2

24. Kim J, Oh WJ, Gaiano N, Yoshida Y, Gu C. Semaphorin 3EPlexin-D1 signaling regulates VEGF function in developmental angiogenesis via a feedback mechanism. Genes Dev. (2011) 25:1399-411. doi: 10.1101/gad.2042011

25. Neufeld G, Kessler O. The semaphorins: versatile regulators of tumour progression and tumour angiogenesis. Nat Rev Cancer. (2008) 8:632-45. doi: $10.1038 / \mathrm{nrc} 2404$

26. Neufeld G, Sabag AD, Rabinovicz N, Kessler O. Semaphorins in angiogenesis and tumor progression. Cold Spring Harb Perspect Med. (2012) 2:a006718. doi: 10.1101/cshperspect.a006718

27. Chauvet S, Cohen S, Yoshida Y, Fekrane L, Livet J, Gayet O, et al. Gating of Sema3E/PlexinD1 signaling by neuropilin-1 switches axonal repulsion to attraction during brain development. Neuron. (2007) 56:807-22. doi: 10.1016/j.neuron.2007.10.019

28. Koncina E, Roth L, Gonthier B, Bagnard D. Role of semaphorins during axon growth and guidance. Adv Exp Med Biol. (2007) 621:50-64. doi: 10.1007/978-0-387-76715-4_4

29. Ishii H, Kubo T, Kumanogoh A, Yamashita T. Th1 cells promote neurite outgrowth from cortical neurons via a mechanism dependent on semaphorins. Biochem Biophys Res Commun. (2010) 402:168-72. doi: 10.1016/j.bbrc.2010.10.029

30. Kantor DB, Chivatakarn O, Peer KL, Oster SF, Inatani M, Hansen MJ, et al. Semaphorin $5 \mathrm{~A}$ is a bifunctional axon guidance cue regulated by heparan and chondroitin sulfate proteoglycans. Neuron. (2004) 44:961-75. doi: 10.1016/j.neuron.2004.12.002

31. Lin L, Lesnick TG, Maraganore DM, Isacson O. Axon guidance and synaptic maintenance: preclinical markers for neurodegenerative disease and therapeutics. Trends Neurosci. (2009) 32:142-9. doi: 10.1016/j.tins.2008.11.006

32. Suto F, Ito K, Uemura M, Shimizu M, Shinkawa Y, Sanbo M, et al. Plexina4 mediates axon-repulsive activities of both secreted and transmembrane semaphorins and plays roles in nerve fiber guidance. J Neurosci. (2005) 25:3628-37. doi: 10.1523/JNEUROSCI.4480-04.2005

33. Suto F, Tsuboi M, Kamiya H, Mizuno H, Kiyama Y, Komai S, et al. Interactions between plexin-A2, plexin-A4, and semaphorin $6 \mathrm{~A}$ control lamina-restricted projection of hippocampal mossy fibers. Neuron. (2007) 53:535-47. doi: 10.1016/j.neuron.2007.01.028

34. Curley JL, Catig GC, Horn-Ranney EL, Moore MJ. Sensory axon guidance with semaphorin $6 \mathrm{~A}$ and nerve growth factor in a biomimetic choice point model. Biofabrication. (2014) 6:035026. doi: 10.1088/1758-5082/6/3/035026

35. Pasterkamp RJ, Peschon JJ, Spriggs MK, Kolodkin AL. Semaphorin 7A promotes axon outgrowth through integrins and MAPKs. Nature. (2003) 424:398-405. doi: 10.1038/nature01790

36. Miao HQ, Soker S, Feiner L, Alonso JL, Raper JA, Klagsbrun M. Neuropilin1 mediates collapsin-1/semaphorin III inhibition of endothelial cell motility: functional competition of collapsin-1 and vascular endothelial growth factor165. J Cell Biol. (1999) 146:233-42. doi: 10.1083/jcb.146.1.233

37. Yu W, Bai Y, Han N, Wang F, Zhao M, Huang L, et al. Inhibition of pathological retinal neovascularization by semaphorin 3A. Mol Vis. (2013) 19:1397-405.

38. Acevedo LM, Barillas S, Weis SM, Gothert JR, Cheresh DA. Semaphorin 3A suppresses VEGF-mediated angiogenesis yet acts as a vascular permeability factor. Blood. (2008) 111:2674-80. doi: 10.1182/blood-2007-08-110205

39. Adi SD, Eiza N, Bejar J, Shefer H, Toledano S, Kessler O, et al. Semaphorin $3 \mathrm{~A}$ Is Effective in Reducing Both Inflammation and Angiogenesis in a Mouse Model of Bronchial Asthma. Front Immunol. (2019) 10:550. doi: $10.3389 /$ fimmu.2019.00550

40. Guttmann-Raviv N, Shraga-Heled N, Varshavsky A, Guimaraes-Sternberg C, Kessler O, Neufeld G. Semaphorin-3A and semaphorin-3F work together to repel endothelial cells and to inhibit their survival by induction of apoptosis. J Biol Chem. (2007) 282:26294-305. doi: 10.1074/jbc.M609711200

41. Varshavsky A, Kessler O, Abramovitch S, Kigel B, Zaffryar S, Akiri G, et al. Semaphorin-3B is an angiogenesis inhibitor that is inactivated by furin-like pro-protein convertases. Cancer Res. (2008) 68:6922-31. doi: 10.1158/0008-5472.CAN-07-5408

42. Rolny C, Capparuccia L, Casazza A, Mazzone M, Vallario A, Cignetti A, et al. The tumor suppressor semaphorin $3 \mathrm{~B}$ triggers a prometastatic program mediated by interleukin 8 and the tumor microenvironment. J Exp Med. (2008) 205:1155-71. doi: 10.1084/jem.20072509

43. Banu N, Teichman J, Dunlap-Brown M, Villegas G, Tufro A. Semaphorin $3 \mathrm{C}$ regulates endothelial cell function by increasing integrin activity. FASEB J. (2006) 20:2150-2. doi: 10.1096/fj.05-5698fje

44. Maione FF, Molla C, Meda R, Latini L, Zentilin M, Giacca G. et al. Semaphorin $3 \mathrm{~A}$ is an endogenous angiogenesis inhibitor that blocks tumor growth and normalizes tumor vasculature in transgenic mouse models. J Clin Invest. (2009). 119:3356-72. doi: 10.1172/JCI36308

45. Yang WJ, Hu J, Uemura A, Tetzlaff F, Augustin HG, Fischer A. Semaphorin-3C signals through Neuropilin-1 and PlexinD1 receptors to inhibit pathological angiogenesis. EMBO Mol Med. (2015) 7:1267-84. doi: 10.15252/emmm.201404922

46. Toledano SH, Lu A, Palacio K, Ziv O, Kessler S, Schaal G, et al. Barak. A sema3c mutant resistant to cleavage by furin (fr-sema3c) inhibits choroidal neovascularization. PLoS One. (2016). 11:e0168122. doi: 10.1371/journal.pone. 0168122

47. Aghajanian H, Choi C, Ho VC, Gupta M, Singh MK, Epstein JA. Semaphorin $3 \mathrm{~d}$ and semaphorin $3 \mathrm{e}$ direct endothelial motility through distinct molecular signaling pathways. J Biol Chem. (2014) 289:17971-9. doi: $10.1074 /$ jbc.M113.544833

48. Meadows SM, Fletcher PJ, Moran C, Xu K, Neufeld G, Chauvet $\mathrm{S}$, et al. Integration of repulsive guidance cues generates avascular zones that shape mammalian blood vessels. Circ Res. (2012) 110:34-46. doi: 10.1161/CIRCRESAHA.111.249847

49. Mazzotta C, Romano E, Bruni C, Manetti M, Lepri G, BellandoRandone S, et al. Plexin-D1/Semaphorin 3E pathway may contribute to dysregulation of vascular tone control and defective angiogenesis in systemic sclerosis. Arthritis Res Ther. (2015) 17:221. doi: 10.1186/s13075-0150749-4

50. Regano D, Visintin A, Clapero F, Bussolino F, Valdembri D, Maione F, et al. Sema3F (Semaphorin 3F) selectively drives an extraembryonic proangiogenic program. Arterioscler Thromb Vasc Biol. (2017) 37:1710-21. doi: 10.1161/ATVBAHA.117.308226

51. Buehler A, Sitaras N, Favret S, Bucher F, Berger S, Pielen A, et al. Semaphorin $3 \mathrm{~F}$ forms an anti-angiogenic barrier in outer retina. FEBS Lett. (2013) 587:1650-5. doi: 10.1016/j.febslet.2013.04.008

52. Meda C, Molla F, De Pizzol M, Regano D, Maione F, Capano S, et al. Semaphorin $4 \mathrm{~A}$ exerts a proangiogenic effect by enhancing vascular endothelial growth factor-A expression in macrophages. J Immunol. (2012) 188:4081-92. doi: 10.4049/jimmunol.1101435

53. Toyofuku T, Yabuki M, Kamei J, Kamei M, Makino N, Kumanogoh A, et al. Semaphorin-4A, an activator for T-cell-mediated immunity, suppresses angiogenesis via Plexin-D1. EMBO J. (2007) 26:1373-84. doi: $10.1038 /$ sj.emboj.7601589 
54. Iyer AS, Chapoval SP. Neuroimmune semaphorin 4a in cancer angiogenesis and inflammation: a promoter or a suppressor? Int J Mol Sci. (2018). 20:E124. doi: 10.3390/ijms20010124

55. Conrotto P, Valdembri D, Corso S, Serini G, Tamagnone L, Comoglio PM, et al. Sema4D induces angiogenesis through met recruitment by Plexin B1. Blood. (2005) 105:4321-9. doi: 10.1182/blood-2004-07-2885

56. Zhou H, Binmadi NO, Yang YH, Proia P, Basile JR. Semaphorin 4D cooperates with VEGF to promote angiogenesis and tumor progression. Angiogenesis. (2012) 15:391-407. doi: 10.1007/s10456-012-9268-y

57. Fiore R, Rahim B, Christoffels VM, Moorman AF, Puschel AW. Inactivation of the Sema5a gene results in embryonic lethality and defective remodeling of the cranial vascular system. Mol Cell Biol. (2005) 25:2310-9. doi: 10.1128/MCB.25.6.2310-2319.2005

58. Sadanandam A, Rosenbaugh EG, Singh S, Varney M, Singh RK. Semaphorin $5 \mathrm{~A}$ promotes angiogenesis by increasing endothelial cell proliferation, migration, and decreasing apoptosis. Microvasc Res. (2010) 79:1-9. doi: 10.1016/j.mvr.2009.10.005

59. Lu Y, Xu Q, Chen L, Zuo Y, Liu S, Hu Y, et al. Expression of semaphorin 6D and its receptor plexin-A1 in gastric cancer and their association with tumor angiogenesis. Oncol Lett. (2016) 12:3967-74. doi: 10.3892/ol.2016.5208

60. Ghanem RC, Han KY, Rojas J, Ozturk O, Kim DJ, Jain S, et al. Semaphorin 7A promotes angiogenesis in an experimental corneal neovascularization model. Curr Eye Res. (2011) 36:989-96. doi: 10.3109/02713683.2011. 593730

61. Hu S, Liu Y, You T, Zhu L. Semaphorin 7A promotes VEGFA/VEGFR2mediated angiogenesis and intraplaque neovascularization in $\mathrm{ApoE}(-/-)$ mice. Front Physiol. (2018) 9:1718. doi: 10.3389/fphys.2018.01718

62. Garcia-Areas R, Libreros S, Amat S, Keating P, Carrio R, Robinson P, et al. Semaphorin7A promotes tumor growth and exerts a pro-angiogenic effect in macrophages of mammary tumor-bearing mice. Front Physiol. (2014) 5:17. doi: 10.3389/fphys.2014.00017

63. Sakurai A, Gavard J, Annas-Linhares Y, Basile JR, Amornphimoltham P, Palmby TR, et al. Semaphorin 3E initiates antiangiogenic signaling through plexin D1 by regulating Arf6 and R-Ras. Mol Cell Biol. (2010) 30:3086-98. doi: 10.1128/MCB.01652-09

64. Zhou YF, Chen AQ, Wu JH, Mao L, Xia YP, Jin HJ, et al. Sema3E/PlexinD1 signaling inhibits postischemic angiogenesis by regulating endothelial DLL4 and filopodia formation in a rat model of ischemic stroke. FASEB J. (2019) 33:4947-61. doi: 10.1096/fj.201801706RR

65. Mumblat Y, Kessler O, Ilan N, Neufeld G. Full-length semaphorin-3C is an inhibitor of tumor lymphangiogenesis and metastasis. Cancer Res. (2015) 75:2177-86. doi: 10.1158/0008-5472.CAN-14-2464

66. Valiulyte I, Curkunaviciute R, Ribokaite L, Kazlauskas A, Vaitkeviciute M, Skauminas $\mathrm{K}$, et al. The anti-tumorigenic activity of Sema3C in the chick embryo chorioallantoic membrane model. Int J Mol Sci. (2019) 20:E5672. doi: 10.3390/ijms20225672

67. Granziero L, Circosta P, Scielzo C, Frisaldi E, Stella S, Geuna M, et al. CD100/Plexin-B1 interactions sustain proliferation and survival of normal and leukemic CD5+ B lymphocytes. Blood. (2003) 101:1962-9. doi: 10.1182/blood-2002-05-1339

68. Deaglio S, Vaisitti T, Bergui L, Bonello L, Horenstein AL, Tamagnone $\mathrm{L}$, et al. CD38 and CD100 lead a network of surface receptors relaying positive signals for B-CLL growth and survival. Blood. (2005) 105:3042-50. doi: 10.1182/blood-2004-10-3873

69. Evans EE, Jonason ASJr, Bussler H, Torno S, Veeraraghavan J, Reilly C, et al. Antibody blockade of semaphorin 4D promotes immune infiltration into tumor and enhances response to other immunomodulatory therapies. Cancer Immunol Res. (2015) 3:689-701. doi: 10.1158/2326-6066.CIR-14-0171

70. Xia Y, Cai XY, Fan JQ, Zhang LL, Ren JH, Li ZY, et al. The role of sema4D in vasculogenic mimicry formation in non-small cell lung cancer and the underlying mechanisms. Int J Cancer. (2019) 144:2227-38. doi: 10.1002/ijc.31958

71. Hanahan D, Coussens LM. Accessories to the crime: functions of cells recruited to the tumor microenvironment. Cancer Cell. (2012) 21:309-22. doi: 10.1016/j.ccr.2012.02.022

72. Suarez-Lopez L, Sriram G, Kong YW, Morandell S, Merrick KA, Hernandez $\mathrm{Y}$, et al. MK2 contributes to tumor progression by promoting M2 macrophage polarization and tumor angiogenesis. Proc Natl Acad Sci USA. (2018) 115:E4236-44. doi: 10.1073/pnas.1722020115

73. Holmes S, Downs AM, Fosberry A, Hayes PD, Michalovich D, Murdoch P, et al. Sema7A is a potent monocyte stimulator. Scand J Immunol. (2002) 56:270-5. doi: 10.1046/j.1365-3083.2002.01129.x

74. Black SA, Nelson AC, Gurule NJ, Futscher BW, Lyons TR. Semaphorin 7a exerts pleiotropic effects to promote breast tumor progression. Oncogene. (2016) 35:5170-8. doi: 10.1038/onc.2016.49

75. Tordjman R, Lepelletier Y, Lemarchandel V, Cambot M, Gaulard P, Hermine $\mathrm{O}$, et al. A neuronal receptor, neuropilin-1, is essential for the initiation of the primary immune response. Nat Immunol. (2002) 3:477-82. doi: 10.1038/ni789

76. Fontenot JD, Gavin MA, Rudensky AY. Foxp3 programs the development and function of $\mathrm{CD} 4{ }^{+} \mathrm{CD} 25^{+}$regulatory T cells. Nat Immunol. (2003) 4:330-6. doi: 10.1038/ni904

77. Milpied P, Renand A, Bruneau JDA, Mendes-da-Cruz Jacquelin S, Asnafi V, Rubio MT, et al. Neuropilin-1 is not a marker of human Foxp3 ${ }^{+}$Treg. Eur J Immunol. (2009) 39:1466-71. doi: 10.1002/eji.200839040

78. Delgoffe GM, Woo SR, Turnis ME, Gravano DM, Guy C, Overacre AE, et al. Stability and function of regulatory $\mathrm{T}$ cells is maintained by a neuropilin-1semaphorin-4a axis. Nature. (2013) 501:252-6. doi: 10.1038/nature12428

79. Audiger C, Rahman MJ, Yun TJ, Tarbell KV, Lesage S. The Importance of Dendritic Cells in Maintaining Immune Tolerance. J Immunol. (2017) 198:2223-31. doi: 10.4049/jimmunol.1601629

80. Takegahara N, Kumanogoh A, Kikutani H. Semaphorins: a new class of immunoregulatory molecules. Philos Trans R Soc Lond B Biol Sci. (2005) 360:1673-80. doi: 10.1098/rstb.2005.1696

81. Rimar D, Nov Y, Rosner I, Slobodin G, Rozenbaum M, Halasz K, et al. Semaphorin 3A: an immunoregulator in systemic sclerosis. Rheumatol Int. (2015) 35:1625-30. doi: 10.1007/s00296-015-3269-2

82. Romano E, Chora I, Manetti M, Mazzotta C, Rosa I, BellandoRandone S, et al. Decreased expression of neuropilin-1 as a novel key factor contributing to peripheral microvasculopathy and defective angiogenesis in systemic sclerosis. Ann Rheum Dis. (2016) 75:1541-9. doi: 10.1136/annrheumdis-2015-207483

83. Miller LE, Weidler C, Falk W, Angele P, Schaumburger J, Scholmerich J, et al. Increased prevalence of semaphorin $3 \mathrm{C}$, a repellent of sympathetic nerve fibers, in the synovial tissue of patients with rheumatoid arthritis. Arthritis Rheum. (2004) 50:1156-63. doi: 10.1002/art.20110

84. Williams A, Piaton G, Aigrot MS, Belhadi A, Theaudin M, Petermann F, et al. Semaphorin 3A and 3F: key players in myelin repair in multiple sclerosis? Brain. (2007) 130(Pt 10):2554-65. doi: 10.1093/brain/awm202

85. Okuno $\mathrm{T}$, Nakatsuji $\mathrm{Y}$, Kumanogoh A. The role of immune semaphorins in multiple sclerosis. FEBS Lett. (2011) 585:3829-35. doi: 10.1016/j.febslet.2011.03.033

86. Shi W, Kumanogoh A, Watanabe C, Uchida J, Wang X, Yasui T, et al. The class IV semaphorin CD100 plays nonredundant roles in the immune system: defective B and T cell activation in CD100-deficient mice. Immunity. (2000) 13:633-42. doi: 10.1016/S1074-7613(00)00063-7

87. Wang L, Song G, Zheng Y, Tan W, Pan J, Zhao Y, et al. Expression of Semaphorin 4A and its potential role in rheumatoid arthritis. Arthritis Res Ther. (2015) 17:227. doi: 10.1186/s13075-015-0734-y

88. Okuno T, Nakatsuji Y, Moriya M, Takamatsu H, Nojima S, Takegahara $\mathrm{N}$, et al. Roles of Sema4D-plexin-B1 interactions in the central nervous system for pathogenesis of experimental autoimmune encephalomyelitis. J Immunol. (2010) 184:1499-506. doi: 10.4049/jimmunol.09 03302

89. Mizui M, Kumanogoh A, Kikutani H. Immune semaphorins: novel features of neural guidance molecules. J Clin Immunol. (2009) 29:1-11. doi: 10.1007/s10875-008-9263-7

90. Garcia S. Role of semaphorins in immunopathologies and rheumatic diseases. Int J Mol Sci. (2019) 20:E374. doi: 10.3390/ijms20020374

91. Catalano A. The neuroimmune semaphorin-3A reduces inflammation and progression of experimental autoimmune arthritis. J Immunol. (2010) 185:6373-83. doi: 10.4049/jimmunol.0903527

92. Cozacov R, Halasz K, Haj T, Vadasz Z. Semaphorin 3A: is a key player in the pathogenesis of asthma. Clin Immunol. (2017) 184:70-2. doi: 10.1016/j.clim.2017.05.011 
93. Liu LN, Li XM, Ye DQ, Pan HF. Emerging role of semaphorin$3 \mathrm{~A}$ in autoimmune diseases. Inflammopharmacology. (2018) 26:655-65. doi: 10.1007/s10787-018-0484-y

94. Lepelletier Y, Moura IC, Hadj-Slimane R, Renand A, Fiorentino S, Baude C, et al. Immunosuppressive role of semaphorin-3A on $\mathrm{T}$ cell proliferation is mediated by inhibition of actin cytoskeleton reorganization. Eur J Immunol. (2006) 36:1782-93. doi: 10.1002/eji.200535601

95. Solomon BD, Mueller C, Chae WJ, Alabanza LM, Bynoe MS. Neuropilin1 attenuates autoreactivity in experimental autoimmune encephalomyelitis. Proc Natl Acad Sci USA. (2011) 108:2040-5. doi: 10.1073/pnas.1008721108

96. Lepelletier Y, Lecourt S, Renand A, Arnulf B, Vanneaux V, Fermand JP, et al. Galectin-1 and semaphorin-3A are two soluble factors conferring Tcell immunosuppression to bone marrow mesenchymal stem cell. Stem Cells Dev. (2010) 19:1075-9. doi: 10.1089/scd.2009.0212

97. Vadasz Z, Toubi E. Semaphorin 3A - a marker for disease activity and a potential putative disease-modifying treatment in systemic lupus erythematosus. Lupus. (2012) 21:1266-70. doi: 10.1177/0961203312456753

98. Vadasz Z, Haj T, Halasz K, Rosner I, Slobodin G, Attias D, et al. Semaphorin $3 \mathrm{~A}$ is a marker for disease activity and a potential immunoregulator in systemic lupus erythematosus. Arthritis Res Ther. (2012) 14:R146. doi: 10.1186/ar3881

99. Wang P, Mao YM, Liu LN, Zhao CN, Li XM, Pan HF. Decreased expression of semaphorin $3 \mathrm{~A}$ and semaphorin $7 \mathrm{~A}$ levels and its association with systemic lupus erythematosus. Immunol Invest. (2020) 49:69-80. doi: 10.1080/08820139.2019.1649280

100. Rezaeepoor M, Shapoori S, Ganjalikhani-Hakemi M, Etemadifar M, Alsahebfosoul F, Eskandari N, et al. Decreased expression of Sema3A, an immune modulator, in blood sample of multiple sclerosis patients. Gene. (2017) 610:59-63. doi: 10.1016/j.gene.2017.02.013

101. Matucci-Cerinic M, Kahaleh B, Wigley FM. Review: evidence that systemic sclerosis is a vascular disease. Arthritis Rheum. (2013) 65:1953-62. doi: 10.1002/art.37988

102. Piaton G, Aigrot MS, Williams A, Moyon S, Tepavcevic V, Moutkine I, et al. Class 3 semaphorins influence oligodendrocyte precursor recruitment and remyelination in adult central nervous system. Brain. (2011) 134(Pt 4):1156-67. doi: 10.1093/brain/awr022

103. Tamagnone L, Artigiani S, Chen H, He Z, Ming GI, Song H, et al. Plexins are a large family of receptors for transmembrane, secreted, and GPI-anchored semaphorins in vertebrates. Cell. (1999) 99:71-80. doi: 10.1016/S0092-8674(00)80063-X

104. Kumanogoh A, Kikutani H. Immune semaphorins: a new area of semaphorin research. J Cell Sci. (2003) 116(Pt 17):3463-70. doi: 10.1242/jcs.00674

105. Witherden DA, Watanabe M, Garijo O, Rieder SE, Sarkisyan G, Cronin SJ, et al. The CD100 receptor interacts with its plexin B2 ligand to regulate epidermal gammadelta T cell function. Immunity. (2012) 37:314-25. doi: 10.1016/j.immuni.2012.05.026

106. Alto LT, Terman JR. Semaphorins and their Signaling Mechanisms. Methods Mol Biol. (2017) 1493:1-25. doi: 10.1007/978-1-4939-6448-2_1

107. Yoshida Y, Ogata A, Kang S, Ebina K, Shi K, Nojima S, et al. Semaphorin $4 \mathrm{D}$ contributes to rheumatoid arthritis by inducing inflammatory cytokine production: pathogenic and therapeutic implications. Arthritis Rheumatol. (2015) 67:1481-90. doi: 10.1002/art.39086

108. Kumanogoh A, Marukawa S, Suzuki K, Takegahara N, Watanabe CE, Ch'ng Ishida I, et al. Class IV semaphorin Sema4A enhances T-cell activation and interacts with Tim-2. Nature. (2002) 419:629-33. doi: 10.1038/nature01037

109. Kumanogoh A, Shikina T, Suzuki K, Uematsu S, Yukawa K, Kashiwamura $\mathrm{S}$, et al. Nonredundant roles of Sema4A in the immune system: defective $\mathrm{T}$ cell priming and Th1/Th2 regulation in Sema4A-deficient mice. Immunity. (2005) 22:305-16. doi: 10.1016/j.immuni.2005.01.014

110. Kumanogoh A, Watanabe C, Lee I, Wang X, Shi W, Araki H, et al. Identification of CD72 as a lymphocyte receptor for the class IV semaphorin CD100: a novel mechanism for regulating B cell signaling. Immunity. (2000) 13:621-31. doi: 10.1016/S1074-7613(00)00062-5

111. Takamatsu H, Okuno T, Kumanogoh A. Regulation of immune cell responses by semaphorins and their receptors. Cell Mol Immunol. (2010) 7:83-8. doi: 10.1038/cmi.2009.111

112. Kumanogoh A, Suzuki KE, Ch'ng Watanabe C, Marukawa S, Takegahara N, Ishida I, et al. Requirement for the lymphocyte semaphorin, CD100, in the induction of antigen-specific T cells and the maturation of dendritic cells. $J$ Immunol. (2002) 169:1175-81. doi: 10.4049/jimmunol.169.3.1175

113. Gras C, Eiz-Vesper B, Jaimes Y, Immenschuh S, Jacobs R, Witte $T$, et al. Secreted semaphorin 5A activates immune effector cells and is a biomarker for rheumatoid arthritis. Arthritis Rheumatol. (2014) 66:1461-71. doi: 10.1002/art.38425

114. O'Connor BP, Eun SY, Ye Z, Zozulya AL, Lich JD, Moore CB, et al. Semaphorin 6D regulates the late phase of $\mathrm{CD} 4+\mathrm{T}$ cell primary immune responses. Proc Natl Acad Sci USA. (2008) 105:13015-20. doi: 10.1073/pnas.0803386105

115. Suzuki K, Okuno T, Yamamoto M, Pasterkamp RJ, Takegahara N, Takamatsu H, et al. Semaphorin 7A initiates T-cell-mediated inflammatory responses through alphalbetal integrin. Nature. (2007) 446:680-4. doi: $10.1038 /$ nature 05652

116. Kang HR, Lee CG, Homer RJ, Elias JA. Semaphorin 7A plays a critical role in TGF-betal-induced pulmonary fibrosis. J Exp Med. (2007) 204:1083-93. doi: 10.1084/jem.20061273

117. Kim CW, Cho EH, Lee YJ, Kim YH, Hah YS, Kim DR. Disease-specific proteins from rheumatoid arthritis patients. J Korean Med Sci. (2006) 21:478-84. doi: 10.3346/jkms.2006.21.3.478

118. Giacobini P, Messina A, Morello F, Ferraris N, Corso S, Penachioni J, et al. Semaphorin $4 \mathrm{D}$ regulates gonadotropin hormone-releasing hormone1 neuronal migration through PlexinB1-Met complex. J Cell Biol. (2008) 183:555-66. doi: 10.1083/jcb.200806160

119. Deng S, Hirschberg A, Worzfeld T, Penachioni JY, Korostylev A, Swiercz JM, et al. Plexin-B2, but not Plexin-B1, critically modulates neuronal migration and patterning of the developing nervous system in vivo. J Neurosci. (2007) 27:6333-47. doi: 10.1523/JNEUROSCI.5381-06.2007

120. Belle M, Parray A, Belle M, Chedotal A, Nguyen-Ba-Charvet KT. PlexinA2 and Sema6A are required for retinal progenitor cell migration. Dev Growth Differ. (2016) 58:492-502. doi: 10.1111/dgd.12298

121. Scott GA, McClelland LA, Fricke AF. Semaphorin 7a promotes spreading and dendricity in human melanocytes through betal-integrins. I Invest Dermatol. (2008) 128:151-61. doi: 10.1038/sj.jid.5700974

122. Delorme G, Saltel F, Bonnelye E, Jurdic P, Machuca-Gayet I. Expression and function of semaphorin 7A in bone cells. Biol Cell. (2005) 97:589-97. doi: 10.1042/BC20040103

123. Gan Y, Reilkoff R, Peng X, Russell T, Chen Q, Mathai SK, et al. Role of semaphorin 7 a signaling in transforming growth factor betal-induced lung fibrosis and scleroderma-related interstitial lung disease. Arthritis Rheum. (2011) 63:2484-94. doi: 10.1002/art.30386

124. Gutierrez-Franco A, Eixarch H, Costa C, Gil V, Castillo M, Calvo-Barreiro L, et al. Semaphorin 7A as a potential therapeutic target for multiple sclerosis. Mol Neurobiol. (2017) 54:4820-31. doi: 10.1007/s12035-016-0154-2

125. Xie J, Wang H. Semaphorin $7 \mathrm{~A}$ as a potential immune regulator and promising therapeutic target in rheumatoid arthritis. Arthritis Res Ther. (2017) 19:10. doi: 10.1186/s13075-016-1217-5

126. Costa C, Martinez-Saez E, Gutierrez-Franco A, Eixarch H, Castro Z, Ortega-Aznar A, et al. Expression of semaphorin 3A, semaphorin 7A and their receptors in multiple sclerosis lesions. Mult Scler. (2015) 21:1632-43. doi: 10.1177/1352458515599848

127. Kopp MA, Brommer B, Gatzemeier N, Schwab JM, Pruss H. Spinal cord injury induces differential expression of the profibrotic semaphorin 7A in the developing and mature glial scar. Glia. (2010) 58:1748-56. doi: $10.1002 /$ glia.21045

128. Casazza A, Fu X, Johansson I, Capparuccia L, Andersson F, Giustacchini A, et al. Systemic and targeted delivery of semaphorin $3 \mathrm{~A}$ inhibits tumor angiogenesis and progression in mouse tumor models. Arterioscler Thromb Vasc Biol. (2011) 31:741-9. doi: 10.1161/ATVBAHA.110. 211920

129. Kessler O, Shraga-Heled N, Lange T, Gutmann-Raviv N, Sabo E, Baruch $\mathrm{L}$, et al. Semaphorin-3F is an inhibitor of tumor angiogenesis. Cancer Res. (2004) 64:1008-15. doi: 10.1158/0008-5472.CAN-03-3090

130. Serini G, Bussolino F, Maione F, Giraudo E. Class 3 semaphorins: physiological vascular normalizing agents for anti-cancer therapy. J Intern Med. (2013) 273:138-55. doi: 10.1111/joim.12017

131. Bielenberg DR, Hida Y, Shimizu A, Kaipainen A, Kreuter M, Kim CC, et al. Semaphorin 3F, a chemorepulsant for endothelial cells, induces a poorly 
vascularized, encapsulated, nonmetastatic tumor phenotype. J Clin Invest. (2004) 114:1260-71. doi: 10.1172/JCI21378

132. Gu C, Yoshida Y, Livet J, Reimert DV, Mann F, Merte J, et al. Semaphorin $3 \mathrm{E}$ and plexin-D1 control vascular pattern independently of neuropilins. Science. (2005) 307:265-8. doi: 10.1126/science.1105416

133. Moriya J, Minamino T, Tateno K, Okada S, Uemura A, Shimizu I, et al. Inhibition of semaphorin as a novel strategy for therapeutic angiogenesis. Circ Res. (2010) 106:391-8. doi: 10.1161/CIRCRESAHA.109. 210815

134. Sabag AD, Bode J, Fink D, Kigel B, Kugler W, Neufeld G. Semaphorin-3D and semaphorin-3E inhibit the development of tumors from glioblastoma cells implanted in the cortex of the brain. PLoS ONE. (2012) 7:e42912. doi: 10.1371/journal.pone. 0042912

135. Casazza A, Kigel B, Maione F, Capparuccia L, Kessler O, Giraudo E, et al. Tumour growth inhibition and anti-metastatic activity of a mutated furin-resistant Semaphorin 3E isoform. EMBO Mol Med. (2012) 4:234-50. doi: 10.1002/emmm.201100205

136. Bejar J, Kessler O, Sabag AD, Sabo E, Itzhak OB, Neufeld G, et al. Semaphorin3A: a potential therapeutic tool for lupus nephritis. Front Immunol. (2018) 9:634. doi: 10.3389/fimmu.2018.00634

137. Vadasz Z, Haj T, Balbir A, Peri R, Rosner I, Slobodin G, et al. A regulatory role for CD72 expression on B cells in systemic lupus erythematosus. Semin Arthritis Rheum. (2014) 43:767-71. doi: 10.1016/j.semarthrit.2013. 11.010

138. Kong JS, Yoo SA, Kim JW, Yang SP, Chae CB, Tarallo V, et al. Antineuropilin-1 peptide inhibition of synoviocyte survival, angiogenesis, and experimental arthritis. Arthritis Rheum. (2010) 62:179-90. doi: $10.1002 /$ art. 27243

139. Shirvan A, Kimron M, Holdengreber V, Ziv I, Ben-Shaul Y, Melamed S, et al. Anti-semaphorin 3A antibodies rescue retinal ganglion cells from cell death following optic nerve axotomy. J Biol Chem. (2002) 277:49799-807. doi: 10.1074/jbc.M204793200

140. Fisher TL, Seils J, Reilly C, Litwin V, Green L, Salkowitz-Bokal J, et al. Saturation monitoring of VX15/2503, a novel semaphorin $4 \mathrm{D}$-specific antibody, in clinical trials. Cytometry B Clin Cytom. (2016) 90:199-208. doi: 10.1002/cyto.b.21338

141. Biname F, Pham-Van LD, Spenle C, Jolivel V, Birmpili D, Meyer LA, et al. Disruption of Sema3A/Plexin-A1 inhibitory signalling in oligodendrocytes as a therapeutic strategy to promote remyelination. EMBO Mol Med. (2019) 11:e10378. doi: 10.15252/emmm.201910378

Conflict of Interest: The authors declare that the research was conducted in the absence of any commercial or financial relationships that could be construed as a potential conflict of interest.

Copyright (๑) 2020 Iragavarapu-Charyulu, Wojcikiewicz and Urdaneta. This is an open-access article distributed under the terms of the Creative Commons Attribution License (CC BY). The use, distribution or reproduction in other forums is permitted, provided the original author(s) and the copyright owner(s) are credited and that the original publication in this journal is cited, in accordance with accepted academic practice. No use, distribution or reproduction is permitted which does not comply with these terms. 